\title{
Empowering Students Against 'Racism' in Assessment Practices of English Test Proficiency through Genre-Based Pedagogies
}

\author{
Yulizar Komarawan \\ Darul Hikam International School \\ yulizar.space@gmail.com
}

\begin{abstract}
This paper demonstrates that genre-based pedagogy can contribute to the improvement of students' English skill especially argumentative writing skills which are needed in assessment practices of English test proficiency such as IELTS. To reach the goal of the study, a qualitative research design was used. Specifically, a qualitative case study was employed since, in this study, the writer presented detailed linguistic analyses of student's writings. The data was a collections of students' writings in various stages, which were then analyzed using the framework 3x3 matrix developed by Humprey and her colleagues (Humprey, Martin, Dreyfus, \& Mahboob, 2010) within Systemic Functional Theory (hereafter SFL). The findings showed that the students' argumentative writing skills improved; the students could write argumentative texts with clear schematic (level of genre) and use linguistic resources well (level of discourse) after teaching program.
\end{abstract}

Keywords: linguicism, genre-based pedagogy, writing exposition, systemic functional linguistics

\section{INTRODUCTION}

It is generally accepted that direct expressions of racism both verbally and visually are considered inappropriate in today's democratic society. However, consciously or unconsciously racism still exists everywhere including in education field. Even though the racism in this field is not blatant, it can still be seen in several aspects of education such as assessment practices like IELTS. As discussed by Mahboob and Ezster (2010), the standard and norm of language assessment have been defined solely based on academic variety of English, meaning if there is an inclusion of linguistic and cultural diversity particularly in writing made by candidates, they will be considered as failure candidates or underachievement . Such racist practices contribute to racism in educational setting. Van Djik \& Teun (1993) defines this kind of racism as elite or institutional racism while Phillipson (1992) calls this as linguicism.

It has been long discussed in the literature that educational discourses where knowledge is distributed are not neutral. Pennycook (2001) points out that knowledge and power are associated with race, class, and gender, and they are also politically and socially constructed. Meanwhile, Bourdieu (1988) believes that knowledge becomes the power in educational discourse, and he further states that the symbolic power is manifested through language. Regarding this perspective, Fairclough (2001) argues that language is a tool to exercise the power, meaning people who master the language can manipulate and control people. In this case, people who can master 'standard' variety of English based on the code of whiteness open up access to power while people with lack of proficiency of the variety "leads to marginalization and discrimination" (Mahboob \& Ezter, 2010, p. 328).

Linguistic discrimination cannot be seen blatantly in educational setting. As Mahboob and Ezster (2010) discussed, such discrimination seems to be masked by various criteria of evaluation. For example, students from non-speaking English countries like Indonesia should take International English Language Testing System (IELTS) to gain entry to a university in English speaking countries. They should meet language criterion. It means that they should meet a 'standard' variety of English which has become the 'code' of whiteness (Mohta, 2006; Mahboob, 2009). If the students cannot follow it, they will be given lower mark or marginalized.

It seems that it is quite difficult for Indonesian students to meet the standard. In fact, they learn English in a multilingual context where English is sometimes conveyed through mother tongues and taught as a subject in several hours in secondary school. The students grown in a multilingual context still struggle with the English language throughout their school life (Martin \& Matthiessen, 2014). Thus, the students need to be empowered so that they can meet the criteria when taking the English proficiency test.

Theorists and researchers have addressed the issue intensively. They propose various "critical language teaching" methods (see Mahboob \& Paltridge, 2013) to empower the marginalized students. The concept of critical language teaching focuses upon helping students to achieve the important goal for them. One of the critical language teachings is genre-based pedagogy. The genre-based approach (GBA) is an approach proposed by Australian researchers and educators which is informed by SFL theory (Christie \& Martin, 1997; Coffin, 2004; 2006; Martin \& Rose, 2007; 2008; Halliday \& Matthiessen, 2004). This approach purpose is to help students from marginalized group to move up their position. They believe 
that students should be explicitly taught the discourses of power and the language-the skills needed to generate various texts - so that students can control the language.

In genre-based pedagogy, genre refers to different types of texts which are used to communicate something with other people in a certain social context (Martin and Rose, 2008) by using different social functions of language, namely ideational referring to technical and specialized terms which are constructed in texts, interpersonal referring to ways to build a relationship between writer and readers, and textual referring to the way text is organized (Martin \& Rose, 2007). The relation of genre, social contexts, and the function of language is illustrated in Figure 1.

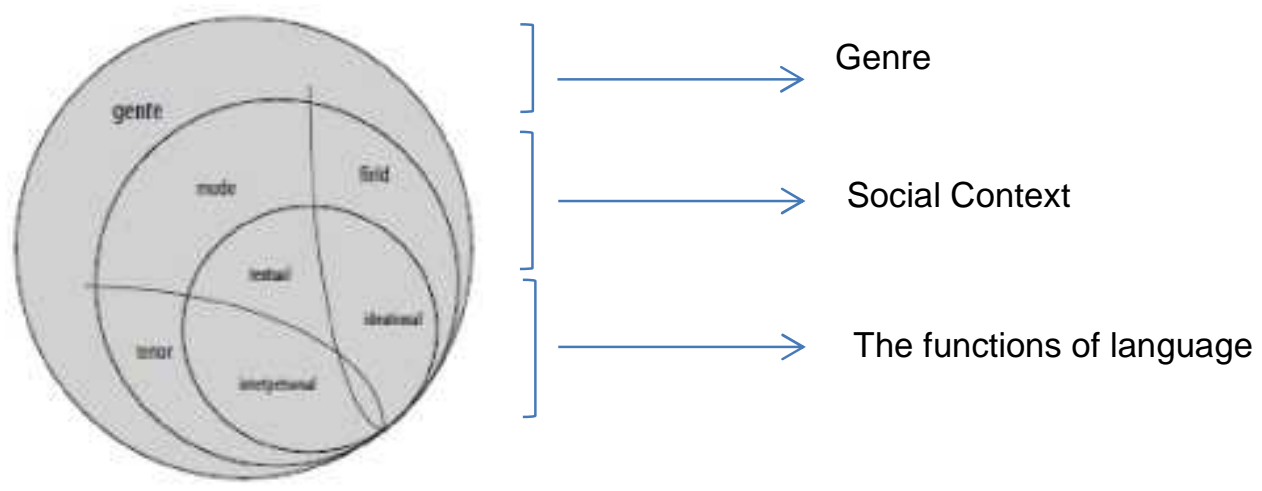

Figure 1.A Stratified model of genre and social context from Martin and Rose (2008)

One of the types of texts is exposition text. Exposition text is texts that present a point of view of a case (Martin and Rose, 2007, 2008). The texts are commonly found within academic setting such as students' essay, political debate, editorials, and commentaries. These texts are also a common part of IELTS test. The organization of the texts includes thesis which introduces the issue and standpoint of the writer, arguments, and restatement of the thesis. In this paper, the writer demonstrates that genre-based pedagogy can contribute to empower students to make an exposition text well so that they can meet the criteria of writing exposition or argumentative texts used in IELTS test. To reach the goal, the writer provides linguistic analysis of the texts written by the participants chosen for this study. The analyses showed what linguistic resources the participants used to construct ideational, interpersonal and textual meanings in their texts. 


\section{METHODOLOGY}

The present study used a qualitative research design. Particularly, the writer employed a case study since it focused on single case (Stake, 1985) and the case was analyzed deeply. It also presented qualitative linguistic analyses which are one of case study characteristics (Travers, 2001). The study was undertaken at Darul Hikam International School in Bandung -West Java, Indonesia. The participants of this study were 6 students of year 12 in the school, who will take IELTS test in the end of academic year and voluntarily participated in the study upon the researcher's giving information on the nature of the study and what was expected of them. The study took 4 meetings for teaching exposition texts.

The texts were chosen since it will be tested in IELTS test. The texts were in form of exposition texts which responded the following question: When a country develops its technology, the traditional skills and ways of life die out. It is pointless to try and keep them alive. To what extent do you agree or disagree with this opinion. The teaching was conducted in September 2016. The writer taught the basic principles of the GBA. Before conducting the teaching, a diagnostic writing task was organized to get information on students' familiarity with the genre in focus. The students' texts were collected at various stages to plot students' development in control of writing skills. The texts written by the students then were closely analyzed by using framework $3 \times 3$ matrix developed by Humphrey and her colleagues(Humprey, Martin, Dreyfus, \& Mahboob, 2010). However, in consideration of the space, the writer only discusses one student's textdiagnostic and the final writing - and the qualitative analyses cover the analyses of linguistic resources (metafunctions) at genre level and discourse level.
At the genre level, the ideational meanings can be seen if the stages of the text achieve its purposes, interpersonal meanings are constructed by providing a convincing answer toward the given task, and textual meanings are reflected through the uses of textual resources which predict or preview the whole texts.

At the discourse level, the ideational meanings are reflected through the uses of generalized vocabulary and logical relationship in the text, the interpersonal meanings can be seen through the uses of objectifying, indirect evaluative resources as well as expanding resources. The textual meanings are reflected through the uses of cohesive resources to make information flow smoothly

\section{RESULT AND DISCUSSION}

This section presents the results of the linguistic analyses of the texts written by a student chosen for this study. The analyses showed linguistic resources that are used by the student to construct ideational, interpersonal and textual meanings in her text.

\subsection{The student use of linguistic resources on the level of} genre

In the beginning, the student seemed to be confused to construct her position toward the given task. As shown in the diagnostic writing presented in Table 1, her position is not clear. However, after the student had an explanation how to construct a good exposition text (see Martin and Rose, 2008 for detail discussion of this), she could state thesis statement clearly compared to the diagnostic text. Here, she was able to take a position or stance clearly toward the issue which was formulated in the task. It means ideationally she could achieve the purpose of writing exposition genre, that is, to state her position that traditional skills will die out.

Table 1 Linguistic resource to construct ideational meaning in terms of genre

\begin{tabular}{ll}
\hline Texts & Resources to provide thesis statement \\
\hline Diagnostic writing (I) & $\begin{array}{l}\text { The technology and traditional skills develops, because of the human make it develop. I'm } \\
\text { not agree with "it is pointless to try and keep alive"... }\end{array}$ \\
\hline $\begin{array}{l}\text { The writingproduced } \\
\text { after teaching (II) }\end{array}$ & $\begin{array}{l}\text { In the future, technology of a country will develop. The development of technology will } \\
\text { erode traditional skills. I personally believe that traditional skill will die [outs] because of } \\
\text { the developing technology... }\end{array}$ \\
\hline
\end{tabular}

From the extract above, it can be seen that the student was able to construct a very clear thesis statement toward the issue by the using the words "I personally believe that ..." Linguistically, the words indicated personal position, showing that she agreed with the given topic or case in the question paper.

Interpersonally, the good writings should convince the readers indicating by using authoritative evidence (Mahboob \& Ezster, 2010). Here, she could write the text quite well even though she did not put authoritative sources. To make it sound convincing, she supported her position by providing examples from daily life to support and strengthen her arguments. Through this way, her writing seemed to be legitimate. 
Table 2 Linguistic resources to construct textual meaning in terms of genre

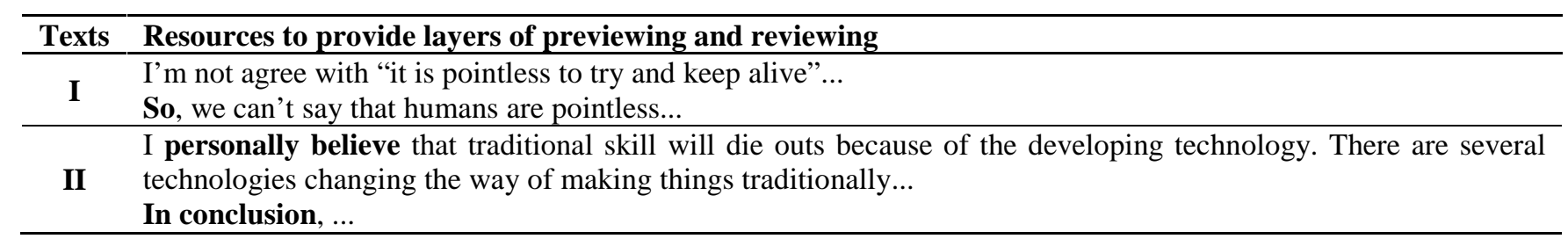

As discussed in the literature (see Martin \& Rose, 2007; 2008), textually a good text should be able to inform readers what it is about in the beginning and what has been discussed. As shown in Table 2, the student's writing after treatment showed clearer opening and closing compared the previous one. Her writing was good enough since in the beginning and final writing she made previewing and

In general, at the level of genre she was able to achieve the criteria of exposition text. It is because she was able to inform readers quickly what the text was about by stating clear thesis statement, make the text sound convincing, and provide clear previewing and reviewing. reviewing. To predict the text, she used the words like "there are several ..." By using the words, she was telling the readers or assessors about the content of the whole text. Meanwhile, to sum up her points, she used the words "In conclusion..." This stage has function to strengthen her position toward the issue.

3.2 The student use of linguistic resources on the level of discourse

At the level of discourse, ideational meanings are constructed through the use of linguistic resources "to generalize field and build logical relationships" (Mahboob and Ezster, 2010, p. 345). The examples of those things can be seen in the following table.

Table 3 Linguistic resources to construct ideational meaning in terms of discourse (field)

\begin{tabular}{|c|c|c|}
\hline Text & Expression generalizing field & Logical Relation \\
\hline I & $\begin{array}{l}\text { Technology - robot, hand phone, batik } \\
\text { print } \\
\text { Traditional skills - batik tulis }\end{array}$ & $\begin{array}{l}\text { For example, someone make to robot to accompany him/her... } \\
\text { Then, robot is one of the robot ... } \\
\text { Besides that if traditional skill to develop... }\end{array}$ \\
\hline II & $\begin{array}{l}\text { Traditional skills - batik tulis, bekam } \\
\text { Technology - batik print, modern } \\
\text { equipment }\end{array}$ & $\begin{array}{l}\text { In the future, technology of country will develop... } \\
\text { Not only "batik tulis", medicine [made] from traditional skill will die } \\
\text { outs... }\end{array}$ \\
\hline
\end{tabular}

From Table 3, it can be seen that both in the first and second writing the student is able to construct the field. She used the words which refer to the concept of technology such robot, hand phone, batik print and the concept of traditional skills such as batik tulis. However, in the first writing it was found that she seemed to have problem with connecting ideas, showing by misused logical connectors. After she was taught to linguistic resources to organize her words, she could discuss the topic in a good way. It is because she used the logical relationship more clearly.

In terms of interpersonal meanings, a good text should contain indirect evaluation, quotation, and expanding and contracting resources indicating by using modal verbs (Humprey, Martin, Dreyfus, \& Mahboob,
2010). Table 4 shows the linguistic resources used by the student to build interpersonal meaning at this level. Compared to the diagnostic writing, the arguments provided by the student after the treatment are quite convincing and put in a logical way. It is because in the text she used expanding resources (modality) such as will more appropriately than the previous one when writing the arguments. Furthermore, although she did not put authoritative sources, she still convinced readers. It was because when presenting the arguments she avoided using the pronoun indicating personal way such as I or my and provided the arguments taken from daily life to make it believable even though she did not put authoritative sources. 
Table 4. Linguistic resources to construct interpersonal meaning in terms of discourse (tenor)

\begin{tabular}{cl}
\hline Text & Resources to provide expanding \\
\hline I & $\begin{array}{l}\text { Because they're not keep humans live ... } \\
\text { It will be different with "batik tulis" ... }\end{array}$ \\
\hline II & $\begin{array}{l}\text { There will [be] not "batik tulis" anymore... } \\
\text { It will be replaced by "batik print"... }\end{array}$ \\
\hline
\end{tabular}

At the level of discourse, a text is textually categorized as a good one when the information flow clearly (Martin \& Rose, 2007). To make the organization flow clearly, the student used cohesive resources such as referencing, substitution, and conjunction (Humprey, Martin, Dreyfus, \& Mahboob, 2010; Martin \& Rose, 2007). Those resources were found in both texts. However, in Text I the student seemed to use the cohesive resources in wrong way and sporadically while in Text II produced after the teaching program she used the resources quite smoothly. With clear substitution, she had made the information clear.

Table 5. Linguistic resources to construct textual meaning in terms of discourse (mode)

Text Resources to provide cohesive resources

I Someone make a robot to accompany him/her, it is really show that someone is really lonely, because they're ... Besides that if traditional skills develops it will reduce humans creartivity ...

II There will [be] not "batik tulis" anymore it will be replaced by "batik print". It will be replaced by "batik print"...

In general, the student was able to construct the ideational, interpersonal, and textual meanings at the level of discourse. Ideationally, she was able to construct the field and discussed it the logical way. Interpersonally, she was able to make the text sound objective and open for dialog while textually she was able to make information clear by putting correct substitution.

\section{CONCLUSION}

Based on the findings and discussion, it can be said the students' argumentative writing skills improved in which the students could write argumentative texts with clear schematic (the level of genre) and used linguistic resources (at the level of discourse) well. Furthermore, it is also shown that the genre-based pedagogies can be used to improve students' ability in writing exposition texts. It can help students meet the standard language resources in academic contexts such as writing IELTS or TOEFL. Therefore, the students should be taught pedagogy empowerment or the explicit teaching of the basic principle of genre and the linguistic supports. Without such pedagogy empowerment, they will still have problem and struggle to meet the standard language especially.

\section{REFERENCES}

Bourdieu, P. (1988). Language and symbolic power. Cambridge: Polity Press.

Christie, F., \& Martin, J. R. (1997).Genre and institutions: Social processes in the workplace and school. London: Cassell.

Coffin, C. (2004). Arguing about how the world is or how the world should be: the role of argument in IELTS Tests. Journal of English for Academic Purposes, 229-246.

Coffin, C. (2006). Historical discourse: the language of time, cause and evaluation. London: Continuum.
Fairclough, N. (2001). Language and power (2nd ed.). Essex, England: Pearsson Education Ltd.

Halliday, M. A., \& Matthiessen, C. (2004). An introduction to functional grammar (3rd ed.). London: Hodder Arnold.

Humprey, S., Martin, J., Dreyfus, S., \& Mahboob, A. (2010). The $3 \times 3$ : Setting up a linguistic toolkit for teaching academic writing. In A. Mahboob, \& N. Knight, Appliable linguistics (pp. 185-199). London: Continuum.

Mahboob, A. (2009). Racism in the English language teaching industry. In A. Mahboob, \& C. Lipovsky, Studies in applied linguistics and language learning (pp. 23-37). Newcastle upon Tyne: Cambridge Scholars Publishing.

Mahboob, A., \& Ezster, S. (2010). Linguicism and racism in assessment practices in higher education. Linguistics and the Human Science, 325-354.

Mahboob, A., \& Paltridge, B. (2013). Critical discourse analysis and critical applied linguistics. In C. A. Chapelle, The encyclopedia of applied linguistics (pp. 1-7). London: Blackwell Publishing Ltd.

Martin, J. R., \& Matthiessen, C. M. (2014). Modelling and mentoring: Teaching and learning from home through school. In A. Mahboob, \& L. Barrat, Englishes in multilingual contexts - Language variation and education (pp. 137-164). Netherland: Springer.

Martin, J. R., \& Rose, D. (2007). Working with discourse: Meaning beyond the clause (2nd ed.). London: Continuum.

Martin, J. R., \& Rose, D. (2008). Genre relations: Mapping culture. London : Equinox.

Mohta, S. (2006). Racializing ESOL teacher identities in U.S. K-12 public schools. TESOL Quarterly, 495518. 
Pennycook, A. (2001). Critical applied linguistics: A critical introduction. Mahwah, NJ: Lawrence Erlbaum.

Phillipson, R. (1992). Linguistic imperialism. Oxford: Oxford University Press.

Stake, E. (1985). Case study. In J. Nisbet, J. Mergary, \& S. Nisbet, World Yearbook of Education 1985. Research, Policy and Politics. London: Nicholas Publishing Company.

Travers, M. (2001).Qualitative Research through Case Studies. London: SAGE Publications.

Van, D. I. J. K., \& Teun. A. (1993). Elite discourse and racism. Newbury Park: SAGE. 